\title{
Antifungal Potential of Indigenous Medicinal Plants against Myrothecium Leaf Spot of Bitter Gourd (Momordica charantia L.)
}

\author{
Muhammad Abid ${ }^{1}$, Sobia Chohan ${ }^{1 *}$, Mirza Abid Mehmood ${ }^{2}$, Safina Naz ${ }^{3}$, Syed Atif Hasan \\ Naqvi'. \\ ${ }^{1}$ Department of Plant Pathology, Faculty of Agricultural Sciences and Technology, Bahauddin Zakariya University, \\ Multan, Pakistan. ${ }^{2}$ Muhammad Nawaz Sharif University of Agriculture, Multan, Pakistan. ${ }^{3}$ Department of \\ Horticulture, Faculty of Agricultural Sciences and Technology, Bahauddin Zakariya University, Multan, Pakistan.
}

\begin{abstract}
Bitter gourd is of great importance due to its usage against the treatment of numerous ailments in human beings. A comprehensive survey at four localities of Southern Punjab, Pakistan was carried out to determine the severity of Myrothecium leaf spot. Maximum disease severity was at $C_{1}($ Chak $11 / \mathrm{NP})$ and least at $C_{2}$ (Kot Mehtab). Among isolated species Myrothecium roridum was found more prevalent and pathogenic as compared to M. verrucaria. Antifungal activity using solvent extracts of five medicinal plants (Mangifera indica, Melia azedarach, Nicotiana tabacum, Moringa oleifera and Eucalyptus globosum) were evaluated against isolated species by agar well diffusion method at various concentrations $(0.01,0.10,1.0$ and $10.0 \mu \mathrm{g} / \mathrm{mL})$. N. tabacum revealed maximum zone size $(13.40 \mathrm{~mm}$ and $8.28 \mathrm{~mm})$ with ethanol and chloroform solvents respectively followed by M. azedarach $(9.00 \mathrm{~mm}$ and $6.48 \mathrm{~mm})$. However, least inhibition was observed with ethanol and chloroform extracts of E. globosum (6.04mm and $3.88 \mathrm{~mm}$ zone size respectively). Ethanol extracts showed highest activity when compared to chloroform extracts. Qualitative phytochemical analysis showed that all the selected plants are rich in chemical compounds such as alkaloids, terpenoids, flavonoids and phenols whereas Saponins was only present in N. tabacum while absent in rest of the extracts.
\end{abstract}

Key words: Momordica charantia L.; secondary compounds; solvent plant extracts.

\footnotetext{
*Author for correspondence: sobia_mustafa2006@hotmail.com
} 


\section{INTRODUCTION}

Bitter gourd (Momordica charantia L.), also known as "bitter melon" is a tropical vine of the family Cucurbitaceae, widely cultivated in natives of tropical regions of Asia with worldwide distribution in China, Japan and Africa ${ }^{1}$. Bitter gourd is economically important plant having medicinal value and use against cancer, diabetes and many infectious diseases and also considered as a powerful weapon against immunodeficiency virus (HIV) ${ }^{2,3,4}$. The crop is having problems such as low seed germination, small sized and deformed fruit, low yield, Asynchronous flowering and attack of pests and diseases ${ }^{2}$. A number of diseases attack bitter gourd but Myrothecium leaf spot caused by $M$. roridum Tode ex Fr. and M. verrucaria (Alb. Schew) Ditm ex Fr., is a serious pathosystem in cultivated areas. The genus Myrothecium includes eight reported species ${ }^{5}$, out of which many are saprophyte soil inhabitants ${ }^{6}$. M. roridum considered as an important plant pathogen, affecting more than 200 plant species of different botanical families ${ }^{7,8}$ and has been reported as a key pathogen of cucurbits causing leaf spot / blight ${ }^{9,10}$. The isolation of $M$. roridum has been reported from seeds of bottle-gourd ${ }^{11}$, Indian gourd, red gourd, sponge gourd ${ }^{12}$, pumpkin ${ }^{13}$ and melon ${ }^{14}$. As compared to other species $M$. verrucaria has showed a high incidence on seeds of watermelon ${ }^{15}$ and also responsible for leaf spot disease in bitter gourd ${ }^{16}$. Both $M$. roridum and $M$. verrucaria are soil inhabiting as well as seed transmitted pathogens of wide host range. Murakami et al. (1999) ${ }^{17}$ reported that $M$. roridum develops large necrotic lesions which verified the ability of M. roridum to produce toxins ${ }^{18}$.

Chemical fungicides are being used by farmers world over for the management of fungal disease resulted in increasing production cost and pose threat to human health and environment ${ }^{19}$. However, botanicals or biopesticides are considered to be one of the best substitutes of expensive and hazardous fungicides ${ }^{20}$. As an alternative to chemical fungicides, botanicals have been reported against fungal diseases of plants. Since plant products being rich in active chemical components can be obtained from any plant part viz., seeds, roots, leaves, flowers, bark etc. ${ }^{21,}{ }^{22}$. Phytochemical screening to obtain the knowledge of chemical constituents present in plants and their antimicrobial activities have been reported by earlier scientists ${ }^{23,24,25}$. These secondary metabolites defend host plants against attack of microorganisms, insects and herbivores ${ }^{26}$. In Pakistan, to our best of knowledge no work is reported towards the ecofriendly management of leaf spot disease of bitter gourd. The aims of present investigations were to evaluate the inhibitory effects of organic solvent extracts of indigenous medicinal plants against leaf spot disease of bitter gourd for disparity in their phytochemical properties.

\section{MATERIALS AND METHODS}

\section{Sample collection}

A comprehensive survey of rural areas of District Rahim Yar Khan, Pakistan $\left(27^{\circ} 40^{\prime}-29^{\circ} 16^{\prime}\right.$ north latitudes and $60^{\circ} 45^{\prime}-70^{\circ} 01^{\prime}$ east longitudes) from four different localities $(\mathrm{C} 1=$ Chak $11 / \mathrm{NP}, \mathrm{C} 2=$ Kot Mehtab, C3= Muhammad Pur and C4= Chak 165/P) was conducted during 2014-15. From each locality 20 plants were randomly selected and tagged, naturally infected bitter gourd leaves showing typical symptoms of leaf spot disease were preserved in clean brown paper bags and transported to the Mycology laboratory of Plant Pathology Department, Multan.

\section{Disease Severity}


Management of Myrothecium leaf spot

Forty infected leaves from already tagged plants were randomly selected from each locality for the assessment of disease severity with the help of 0-4 disease rating scale suggested by Vir and Grewel (1974) ${ }^{27}$ where $0=$ no symptoms on leaves, $1=$ $<5 \%$ infection on leaves, $2=5-25 \%$ infection on leaves, $3=25-75 \%$ infection on leaves, $4=>75 \%$ infection on leaves. Percent Disease Index was calculated by the modified formulae suggested by Sultana \& Ghaffar (2009) ${ }^{16}$ :

Percent Disease index $(\mathrm{PDI})=\frac{\text { Sum of all numerical rating }}{\text { Number of leaves assessed }} \quad X \quad \frac{100}{\text { Maximum disease grade }}$

Isolation and morphological characterization of fungal strains

The infected bitter gourd leaf segments $(1 \mathrm{~cm} \times 1 \mathrm{~cm})$ were washed with tap water, surface sterilized with $70 \%$ ethanol for $1 \mathrm{~min}$ and rinsed in five changes of sterile distilled water. Isolation procedure was carried out on Potato Dextrose Agar medium (PDA- Difco) as described by Dhingra \& Sinclair (1985) ${ }^{28}$. Five leaf segments were aseptically plated on solidified PDA and incubated at $25^{\circ} \mathrm{C}$ for one week to facilitate the mycellial growth. Purification of culture was done by single hyphal tip technique, stored at $4^{\circ} \mathrm{C}$ on PDA slants and identified according to the cultural and morphological characters. Morphological characterization of sporodochia, phialides and conidia of resultant fungi were also studied. Size of conidia were measured (length $\mathrm{x}$ width) and compared with characters illustrated by Barnett \& Hunter (1987) ${ }^{29}$. Pathogenicity test was also carried out on healthy seedlings to confirm Koch's postulates.

\section{Plant materials}

Fresh and healthy leaves of selected medicinal plants (Mangifera indica, Melia azedarach, Nicotiana tabacum, Moringa oleifera and Eucalyptus globosum) were collected from local area, identified and authenticated from Department of Botany, Bahauddin Zakariya University, Multan.

\section{Extraction}

The leaves samples were thoroughly washed with tap water, followed by distilled water and finally with ethanol (Merck) to eliminate any traces of contaminants. Blot dried leaves of each sample were then dried in the oven at $50^{\circ} \mathrm{C}$ for 24 hours, homogenized to fine powder and stored in airtight bottles. Ten gm of powdered material was used in Soxhlet apparatus (J.P.Selecta-Spain) with $100 \mathrm{~mL}$ solvents (ethanol and chloroform) for 48 hours. The extract solutions were centrifuged at $6000 \mathrm{rpm}$ for $10 \mathrm{~min}$, filtered with filter paper (Whatman No.1) and concentrated over a water bath at $40^{\circ} \mathrm{C}$. After complete solvent evaporation extract residues were sealed in dark bottles at $4^{\circ} \mathrm{C}$ for further use by Modified method of Nycee et al. $(2012)^{30}$.

\section{Agar well diffusion assay}

Antifungal tests were carried out by Agar well diffusion method (Perez et al., $1990)^{31}$. An aliquot of $100 \mu \mathrm{L}$ spore suspension $\left(10^{6} \mathrm{spores} / \mathrm{mL}\right)$ was streaked on the surface of petri plates having PDA medium. Wells of $8 \mathrm{~mm}$ in diameter were punched in the seeded agar plates with the help of sterile cork borer. About $100 \mu \mathrm{L}$ of plant extracts alone and in combination $(1: 1 \mathrm{v} / \mathrm{v})$ with certain concentrations $(0.01$, $0.10,1.0$ and $10.0 \mu \mathrm{g} / \mathrm{mL}$ ) were added into each well and allowed to diffuse for $1 \mathrm{hr}$ at room temperature. Dimethyl Sulfoxide (DMSO) was used as a control and treated plates were incubated at $25^{\circ} \mathrm{C}$ for 72 hours. Antifungal activity was evaluated by 
measuring the size of zone with a ruler $(\mathrm{mm})$. All the tests were performed in a Completely Randomized Design (CRD) with five replicates.

\section{Phytochemical Screening}

Plant extracts were subjected to phytochemical screening using the methods of Sofowora, $(1993)^{32}$ and Harborne, $(1973)^{33}$.

Alkaloids (Wagner's test): $20 \mathrm{mg}$ of ethanolic extract was warmed with $2 \%$ sulphuric acid $\left(\mathrm{H}_{2} \mathrm{SO}_{4}\right)$ for 1-2 min, filtered and treated with few drops of wagner's reagent. Presence of reddish brown precipitation or turbidity indicated the presence of alkaloids.

Tannins (Ferric chloride test): About 20mg plant extract was dissolved in ethanol, few drops of $0.1 \%$ ferric chloride added and observed for formation of blue black coloration.

Steroids: $2 \mathrm{~mL}$ of acetic anhydride and conc. $\mathrm{H}_{2} \mathrm{SO}_{4}$ added to $50 \mathrm{mg}$ ethanolic plant extract. Blue green ring indicates the presence of steroids.

Terpenoids (Salkowski Test): About $5 \mathrm{~mL}$ extract of each sample was mixed in ( $2 \mathrm{~mL}$ ) chloroform and $(3 \mathrm{~mL})$ conc. $\mathrm{H}_{2} \mathrm{SO}_{4}$ was added carefully to form a layer. Formation of reddish brown coloration at interface indicates the presence of terpenoids.

Saponins: $20 \mathrm{mg}$ of powdered sample was boiled in $5 \mathrm{ml}$ distilled water and shaken vigorously for a stable persistent froth. Three drops of olive oil was mixed vigorously with frothing and observed for formation of emulsion.

Flavonoids: Powdered sample $(20 \mathrm{mg}$ ) was heated with $10 \mathrm{ml}$ of ethyl acetate for $3 \mathrm{~min}$ and filtered. $4 \mathrm{~mL}$ of filterate was mixed with $1 \mathrm{~mL}$ of dilute ammonia solution. A yellow coloration that disappears on addition of conc. Hydrochloric acid indicated the presence of flavonoids.

\section{STATISTICAL ANALYSIS}

The datasets of disease severity, isolation frequency and size of inhibition zone were subjected to analysis of variance (ANOVA) and treatment means were evaluated with Fisher's Least Significance Difference (LSD) test at 5\% level of significance (Steel et al., 1997) ${ }^{34}$ using Analytical Software (2005).

\section{RESULTS}

Four different locations of District Rahim Yar Khan were evaluated for the disease severity of Myrothecium leaf spot and disease symptoms were observed as: yellowing, chlorosis and appearance of brown concentric rings on necrotic areas of leaves, which later coalesce to give the blighted appearance. In advance stages necrotic and chlorotic areas increased in size resulting into curling and death of leaves. Isolates of each species were identified on the basis of morphological characteristics of conidia, conidiophores, sporodochia and phyialides.

Leaflets with characteristics leaf spot symptoms yielded two isolates; $M$. roridum and $M$. verrucaria with varying percentages of PDI. Laboratory experiments confirmed that isolates of $M$. roridum and $M$. verrucaria were pathogenic. Maximum disease severity $63.80 \%$ was observed at locality $\mathrm{C}_{1}$ (Chak 11/ NP) followed by 37.50, 23.80 and $20.60 \%$ at $\mathrm{C}_{3}, \mathrm{C}_{4}$ (Muhammad Pur, Chak $165 \mathrm{P}$ ) and $\mathrm{C}_{2}$ (Kot Mehtab) respectively (Fig 1). 


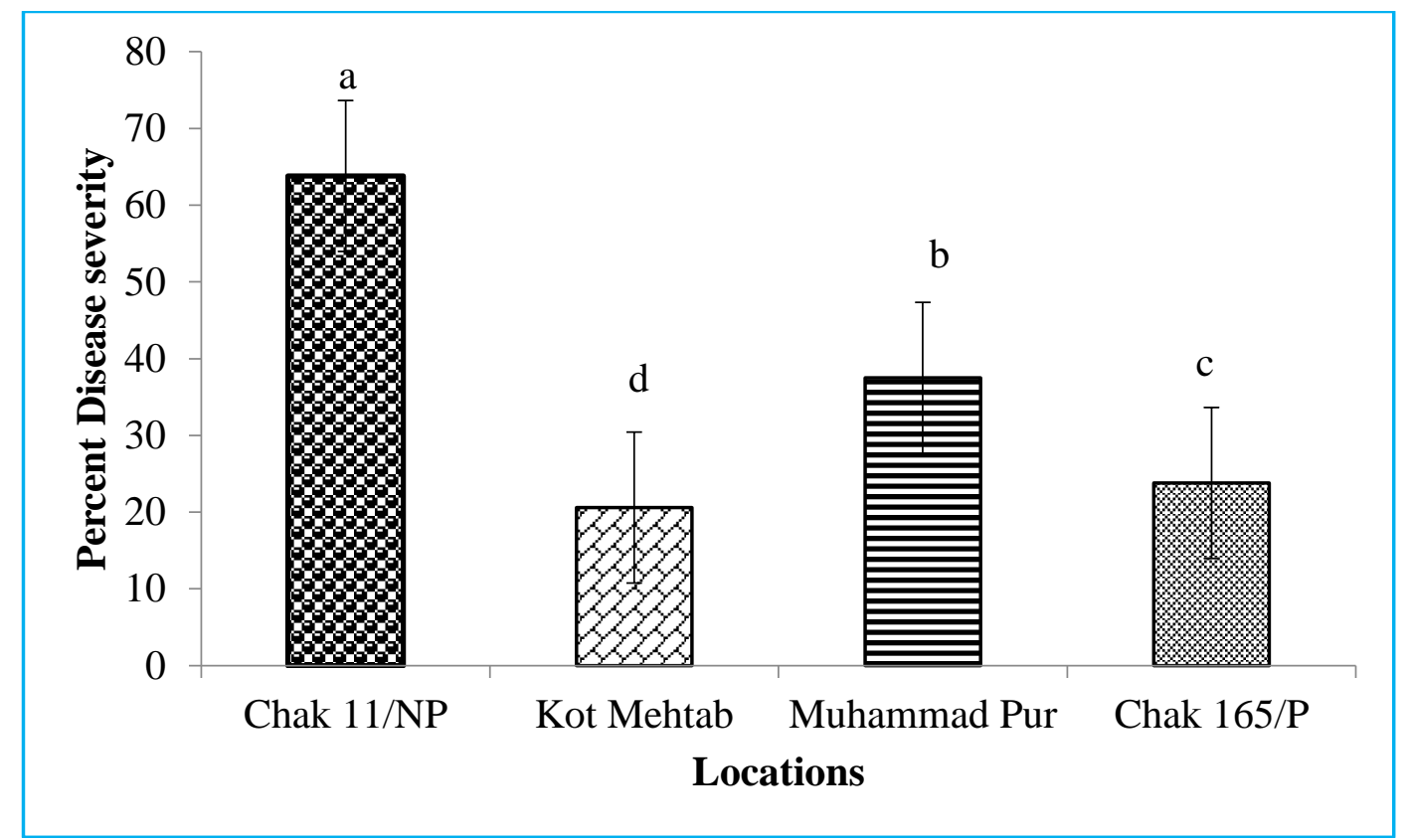

Fig 1: Percent disease severity of Myrothecium leaf spots on different locations

Considering the isolation frequency of leaf samples collected from four different localities yielded two isolates of Myrothecium species. Leaflets from $\mathrm{C}_{1}$ and $\mathrm{C}_{3}$ have both species of Myrothecium (Myr1, Myr2, Myv1, and Myv2) whereas locality $\mathrm{C}_{2}$ samples possess only Myr1 and Myr2. Overall maximum frequency percentage of Myrv1 was isolated from samples of locality $\mathrm{C}_{2}$ followed by $\mathrm{C}_{3}, \mathrm{C}_{4}$ and $\mathrm{C}_{1}$ with $80.00,65.00,60.00$ and $55.00 \%$ respectively while least was of Myv2 only from two localities $\mathrm{C}_{2}$ and $\mathrm{C}_{1}$ with 10 and $5 \%$ respectively (Table 1 ).

Table 1: Frequency isolation (\%) of leaf spot disease of bitter gourd form infected plants

\begin{tabular}{lllll}
\hline \multirow{2}{*}{ *Locality } & \multicolumn{4}{l}{$* * *$ Frequency of Isolation $(\%)$} \\
\cline { 2 - 5 } & $* *$ Myr1 & $* *$ Myr2 & $* *$ Myv1 & $* *$ Myv2 \\
\hline C 1 (Chak 11/ NP) & $55.00 \mathrm{~d}$ & $30.00 \mathrm{e}$ & $10.00 \mathrm{i}$ & $5.00 \mathrm{j}$ \\
C $_{2}$ (Kot Mehtab) & $80.00 \mathrm{a}$ & $20.00 \mathrm{~g}$ & $0.00 \mathrm{k}$ & $0.00 \mathrm{k}$ \\
C $_{3}$ (Muhammad Pur) & $65.00 \mathrm{~b}$ & $20.00 \mathrm{~g}$ & $5.00 \mathrm{j}$ & $10.00 \mathrm{i}$ \\
C4 $_{4}$ (Chak 165/ P) & $60.00 \mathrm{c}$ & $25.00 \mathrm{f}$ & $15.00 \mathrm{~h}$ & $0.00 \mathrm{k}$ \\
\hline
\end{tabular}

**Myr1= Myrothecium roridum Myr2= Myrothecium roridum, Myv1=Myrothecium verrucaria, Myv2= Myrothecium verrucaria. *** Data are means of four replications of two consecutive years. Means showing different letters are statistically significant. $\mathrm{LSD}_{0.05}$ value for comparison of means is 2.52 .

The organic solvent extracts had antifungal effects on the growth of $M$. roridum. Ethanol extraction was superior as compared to chloroform. Ethanol extract of Nicotiana tabacum; in particular, showed maximum inhibition zone size $(22.20 \mathrm{~mm})$ of $M$. roridum using $10 \mu \mathrm{L}$ concentration followed by $13.80,13.60,12.80$ and 12.20 $\mathrm{mm}$ zones of inhibition formed by Melia azedarach, Moringa oleifera, Mangifera indica and Eucalyptus globosum respectively, compared to control (Dimethyl sulphoxide) with zero inhibition zones. It was observed that the zone size increased with an increase in concentration of the extracts. Overall $N$. tabacum showed maximum inhibitory effects towards mycelia growth of $M$. roridum at all concentrations with $13.40 \mathrm{~mm}$ inhibition zone followed by $9.00,7.64,6.32$ and 6.04 
$\mathrm{mm}$ zone of inhibition in M. azedarach, M. oleifera, M. indica and E. globosum respectively (table 2 ).

Table 2: Inhibitory effect of various ethanolic plant extracts at different concentrations on mycelial growth of Myrothecium roridum using agar well diffusion method.

\begin{tabular}{|c|c|c|c|c|c|c|}
\hline \multirow[b]{2}{*}{ Concentrations } & \multicolumn{6}{|c|}{ Size of zone $(\mathrm{mm})$} \\
\hline & $\begin{array}{l}\text { Mangifera } \\
\text { indica }\end{array}$ & $\begin{array}{l}\text { Nicotiana } \\
\text { tabacum }\end{array}$ & $\begin{array}{l}\text { Eucalyptus } \\
\text { globosum }\end{array}$ & $\begin{array}{l}\text { Melia } \\
\text { azedarach }\end{array}$ & $\begin{array}{l}\text { Moringa } \\
\text { oleifera }\end{array}$ & Mean \\
\hline $0.01 \mu l$ & $0.00 \mathrm{j}$ & $11.80 \mathrm{f}-\mathrm{h}$ & $0.00 \mathrm{j}$ & $8.20 \mathrm{i}$ & $7.60 \mathrm{i}$ & $5.52 \mathrm{D}$ \\
\hline $0.1 \mu \mathrm{l}$ & $7.60 \mathrm{i}$ & $15.20 \mathrm{c}$ & $7.40 \mathrm{i}$ & $10.40 \mathrm{~h}$ & $8.20 \mathrm{i}$ & $9.76 \mathrm{C}$ \\
\hline $1 \mu \mathrm{l}$ & $11.20 \mathrm{gh}$ & $17.80 \mathrm{~b}$ & $10.60 \mathrm{~h}$ & $12.60 \mathrm{~d}-\mathrm{g}$ & $8.80 \mathrm{i}$ & $12.20 \mathrm{~B}$ \\
\hline $10 \mu \mathrm{l}$ & $12.80 \mathrm{~d}-\mathrm{f}$ & $22.20 \mathrm{a}$ & $12.20 \mathrm{e}-\mathrm{g}$ & $13.80 \mathrm{~cd}$ & $13.60 \mathrm{de}$ & $14.92 \mathrm{~A}$ \\
\hline DMSO & $0.00 \mathrm{j}$ & $0.00 \mathrm{j}$ & $0.00 \mathrm{j}$ & $0.00 \mathrm{j}$ & $0.00 \mathrm{j}$ & $0.00 \mathrm{E}$ \\
\hline Mean & $6.32 \mathrm{D}$ & $13.40 \mathrm{~A}$ & $6.04 \mathrm{D}$ & $9.00 \mathrm{~B}$ & $7.64 \mathrm{C}$ & \\
\hline
\end{tabular}

Values are means of five replications. Lower case letters after values represent comparison across inhibition percentage and capital letters represent comparison across concentrations and plant extracts. $\mathrm{LSD}_{0.05}$ value for inhibition percentage $=1.43$, for Concentrations $=0.62$ and for Plant extracts $=0.72$.

Correspondingly chloroform extracts of $N$. tabacum also showed better inhibitory effects on mycelia growth of $M$. roridum with maximum $(17.2 \mathrm{~mm})$ inhibition zone at $10 \mu \mathrm{L}$ concentration followed by $12.4,12.2,11.2$ and $10.2 \mathrm{~mm}$ inhibition zone size produced by $M$. azedarach, $M$. oleifera, E. globosum, and M. indica respectively compared to untreated control. In general $N$. tabacum performed best forming 8.28 $\mathrm{mm}$ inhibition zone followed by M. azedarach $(6.48 \mathrm{~mm})$, M. oleifera $(5.88 \mathrm{~mm}), M$. indica $(5.16 \mathrm{~mm})$ and E. globosum $(3.88 \mathrm{~mm})$ inhibition zones (table 3$)$.

Table 3: Inhibitory effect of various plants extracts at different concentrations extracted with chloroform on mycelial growth of Myrothecium roridum using agar well diffusion method.

Size of zone (mm)

\begin{tabular}{lllllll}
\cline { 2 - 6 } Concentration & $\begin{array}{l}\text { Moringa } \\
\text { oleifera }\end{array}$ & $\begin{array}{l}\text { Nicotiana } \\
\text { tabacum }\end{array}$ & $\begin{array}{l}\text { Eucalyptus } \\
\text { globosum }\end{array}$ & $\begin{array}{l}\text { Melia } \\
\text { azedarach }\end{array}$ & $\begin{array}{l}\text { Mangifera } \\
\text { indica }\end{array}$ & Mean \\
\hline $\mathbf{0 . 0 1} \boldsymbol{\mu l}$ & $0.00 \mathrm{i}$ & $0.00 \mathrm{i}$ & $0.00 \mathrm{i}$ & $0.00 \mathrm{i}$ & $0.00 \mathrm{i}$ & $0.00 \mathrm{D}$ \\
$\mathbf{0 . 1} \boldsymbol{\mu l}$ & $7.40 \mathrm{gh}$ & $11.40 \mathrm{~cd}$ & $0.00 \mathrm{i}$ & $8.80 \mathrm{f}$ & $7.20 \mathrm{~h}$ & $6.96 \mathrm{C}$ \\
$\mathbf{1} \boldsymbol{\mu l}$ & $9.80 \mathrm{e}$ & $12.80 \mathrm{~b}$ & $8.20 \mathrm{fg}$ & $11.20 \mathrm{~d}$ & $8.40 \mathrm{f}$ & $10.08 \mathrm{~B}$ \\
$\mathbf{1 0} \boldsymbol{\mu l}$ & $12.20 \mathrm{bc}$ & $17.20 \mathrm{a}$ & $11.20 \mathrm{~d}$ & $12.40 \mathrm{~b}$ & $10.20 \mathrm{e}$ & $12.64 \mathrm{~A}$ \\
$\mathbf{D M S O}$ & $0.00 \mathrm{i}$ & $0.00 \mathrm{i}$ & $0.00 \mathrm{i}$ & $0.00 \mathrm{i}$ & $0.00 \mathrm{i}$ & $0.00 \mathrm{D}$ \\
Mean & $5.88 \mathrm{C}$ & $8.28 \mathrm{~A}$ & $3.88 \mathrm{E}$ & $6.48 \mathrm{~B}$ & $5.16 \mathrm{D}$ &
\end{tabular}

Values are means of five replications. Lower case letters after values represent comparison across inhibition percentage and capital letters represent comparison across concentrations and plant extracts. $\mathrm{LSD}_{0.05}$ value for inhibition percentage $=0.96$, for Concentrations $=0.38$ and for Plant extracts $=0.44$.

Preliminary qualitative phytochemical analysis showed that plant extracts have fair amount of secondary metabolites. Considering the presence or absence of these compounds in medicinal plants utilized, it was observed that alkaloids, terpenoids and flavonoids were present in all plants extracts except E. globosum while tannins were found in $N$. tabacum, M. indica and E. globosum. Steroids were present in $M$. azedarach and $M$. oleifera, whereas, saponins were only present in $N$. tabacum but absent in rest of the plant extracts (table 4). 
Management of Myrothecium leaf spot

Table 4: Analysis of phytochemicals extracted from medicinal plant extracts.

\begin{tabular}{lllllll}
\hline Plants extracts & Alkaloids & Tannins & Steroids & Terpenoids & Saponins & Flavonoids \\
\hline Mangifera indica & + & + & - & + & - & + \\
Melia azedarach & + & - & + & + & - & + \\
Nicotiana tabacum & + & + & - & + & + & + \\
Moringa oleifera & + & - & + & + & - & + \\
Eucalyptus globosum & - & + & - & - & - & - \\
\hline$+=$ Present & $-=$ Absent & & & & &
\end{tabular}

\section{DISCUSSION}

Myrothecium leaf spot of bitter gourd is considered to be the most serious pathosystem of cucurbis in the cultivated areas. During the current research, Myrothecium infestation on various locations of the District Rahim Yar Khan was assessed. We observed Myrothecium species to produce brown to dark brown leaf spots which later on coalesce to give blighted symptoms in the field on the host plants and it seems ${ }^{35}$ a serious threat to vegetable growers of the area. During the in vitro studies of the collected diseases samples of the different locations we found $M$. roridum and $M$. verrucaria both pathogenic and responsible for leaf spot in bitter gourd. We calculated less isolation frequency of $M$. verrucaria revealed that it is a weak pathogen of bitter gourd grown in this area. Our findings are in agreement with the results of earlier workers whom reported $M$. roridum and $M$. verrucaria both as plant pathogens while later is a weaker one ${ }^{7}$. Myrothecium species are soilinhabiting fungi but due to facultative parasitic nature also able to cause disease in aerial parts of economically important host plants ${ }^{6,36,37,38}$. However, M. roridum also identified as a virulent seedborne pathogen ${ }^{15}$. Rain splashes, irrigation water and dew are dissemination agencies of both Myrothecium species. Prolonged hot and humid weather favors the foliar attack of Myrothecium ${ }^{39}$. Two isolates; M. roridum and $M$. verrucaria were isolated and identified and compared with work of earlier scientists ${ }^{36}$. According to some scientists large necrotic lesions are due to necrotrophic nature of fungi that produce toxins in host tissues resulting into death of host tissues and the fungal pathogen colonize over these necrotic areas ${ }^{40,8}$. Though virulence of $M$. roridum was demonstrated on large number of plants but different $M$. roridum isolates revealed variability in virulence but highly aggressive behavior was observed in tomato and cucumber ${ }^{41}$. N. tabacum was found rich in all compounds except steroids and thus possessed excellent fungicidal activity (Taiga et al., 2008) $)^{42}$ which proved that $N$. tabacum was more fungitoxic compared to other plant extract due to the subsistence of tannins in addition to Saponins and flavonoids. These results corroborated with the outcome of other scientists ${ }^{43},{ }^{42}$. Furthermore, phytochemical studies of various plant extracts showed that fungicidal activity is due to presence of tannins, alkaloids, flavonoids and saponins ${ }^{32,44}$. Out of five plants extracts used, all of them showed antimicrobial activity but $N$. tabacum and $M$. azedarach were found more promising ${ }^{45,46,47}$. Plants with more phenolic contents show efficient antioxidant activity ${ }^{48}$. Similarly, according to Ali et al., $(2008)^{49}$ plant possesses natural antioxidants in the form of phenolic compounds such as phenolic acids, tocopherol, flavonoids etc. These results are substantiated with the outcome of 
this study. There is a need to explore more plants possessing antimicrobial potential to use in our organic farming system for cleaner environment.

\section{CONCLUSION}

Use of plant extracts to control fungal pathogen responsible for blight of bitter gourd is ecofriendly approach and an effective alternative to toxic chemical fungicides. Studies are in progress, in the greenhouse and in open fields, to evaluate antifungal effect of these natural substances on bitter gourd development and on qualitative and quantitative fruit production.

\section{ACKNOWLEDGMENTS}

We are very thankful to Department of Plant protection, Pest Warning and Quality Controls of Pesticides, Sadiqabad, Pakistan for assisting us in field surveys during the study.

\section{CONFLICT OF INTEREST DISCLOSER}

There is no conflict of interest among authors regarding the current manuscript.

\section{REFERENCES}

1- Grubben GJH. Tropical vegetable and their genetic resources. IBPGR, Rome. 1977; p. 51-52.

2- Sikder B. Improvement of bitter gourd (Momordica charantia L.) through breeding and biotechnology. Ph.D thesis. Department of Genetics and Breeding, University of Rajshahi, Bangladesh. 2004

3- Shetty AK, Kumar GS, Sambaiah K, Salimath PV. Effect of bitter gourd (Momordica charantia L.) on glycaemic status in streptozotocin induced diabetic rats. Pl Foods Hum Nutr. 2005; 60: 109-112.

4- Paul A, Raychaudhuri SS. Medicinal uses and molecular identification of two Momordica charantia varieties-a review. Electronic J Bio. 2010; 6(2):43-51.

5- Tulloch M. The genus Myrothecium. Mycological Papers. (IMI) 130. 1972; p.44.

6- Costa I, Wanderley PM, Cavalcante MA, Fernandes MJ, Lima DMM. Hyphomycetes from soil of an area affected by copper mining activities in the State of Bahia, Brazil. Braz J Microbiol. 2006; 37 (3): 290-295.

7- Ahrazem O, Gómez-Miranda AP, Bernabé M, Leal JA. Heterogeneity of the genus Myrothecium as revealed by cell wall polysaccharides. Arch Microbiol. 2000; 173: 296302.

8- Murakami R, Kobayashi T, Takahashi K. Myrothecium leaf spot of mulberry caused by Myrothecium verrucaria. J Gen Pl Pathol. 2005; 71: 153-155.

9- Ali S, Wahid A, Murtaza M, Nadeem A. Myrothecium leaf of bitter gourd in Pakistan. Pak J Agric Res. 1988; 9: 598-600.

10-Shakoor S, Chohan S, Riaz A, Perveen R, Naz S, Mehmood MA, Haider MS, Ahmad S. Screening of systemic fungicides and biochemicals against seed borne mycoflora associated with Momordica charantia. Afr J Biotech. 2011; 10(36):6933-40.

11-Shakir AS, Mirza JH. Seed-bornefungi of Bottle gourd from Faisalabad and their control. Pak J Phytopathol. 1992; 4: 54-57.

12-Shakir AS, Mirza JH, Sahi ST, Ahmad F. Detection of seed-borne fungi associated with sponge gourd \{Luffa cylindrical (L.) Roem. \}, their location in different seed components and their control. Pak J Phytopathol. 1995; 7: 140-144.

13-Cabral CS, Henz GP, Moreira AJ, Reis A. New cucurbitaceous hosts of Myrothecium roridum in Amazonas State, Brazil. Trop Pl Pathol. 2009;34(6):402-5. 
14-Fish WW, Bruton BD, Popham TW. Cucurbit host range of Myrothecium roridum isolated from watermelon. Amr J Pl Sci. 2012; 3(03):353.

15-Bharath BG, Lokesh S, Raghavendra VB, Prakash HS, Shetty BG. First Report of the occurrence of Myrothecium verrucaria in watermelon seeds from India. Aust Pl Dis Notes. 2006; 1: 3-4.

16-Sultana N, Ghaffar A. Pathogenesis and control of myrothecium spp., the cause of leaf spot on bitter gourd (Momordica charantia Linn.). Pak J Bot. 2009; 41: 429-433.

17-Murakami R, Yasui H, Shirata A, Kato A. Production of myrotoxin-B by Myrothecium roridum isolated from Myrothecium leaf spot of mulberry in Japan. J Sericult Sci Japan. 1999; 68: 469-477.

18-Kuti JO, Ng TJ, Bean GA. Possible involvement of a pathogen-produced trichothecene metabolite in Myrothecium leaf spot of muskmelon. Physio mol pl pathol.1989; 34(1):4154.

19-Bowers JH, Locke JC. Effect of botanical extracts on the population density of Fusarium oxysporum in soil and control of Fusarium wilt in the greenhouse. Pl Dis. 2000; 84:300 305.

20-Joseph B, Muzafar A, Vinod K. Bioefficacy of Plant Extracts to Control Fusarium solani f. sp. melongenae Incitant of Brinjal Wilt. Global J Biotech \& Biochem. 2008; 3 (2):5659.

21-Cragg GM, David JN. Natural product drug discovery in the next millennium. J Pharm Biol 2001; 39: 8-17.

22-Ivanova D, Gerova D, Chervenkov T, Yankova T. Polyphenols and antioxidant capacity of Bulgarian medicinal plant. J Ethnopharmacol. 2005; 96:145-150.

23-Aqil F, Ahmad I, Mehmood Z. Antioxidant and free radical scavenging properties of twelve traditionally used Indian medicinal plants. Turkish journal of Biology. 2006; 30(3):177-83.

24-Parekh J, Chanda S. Phytochemicals screening of some plants from western region of India. Pl Arch. 2008; 8: 657- 662.

25-Chanda S, Dave R. In vitro models for antioxidant activity evaluation and some medicinal plants possessing antioxidant properties: An overview. Afr J Microbiol Res. 2009; 3(13): 981-996.

26-Cowan MM. Plant products as antimicrobial agents. Clin Microbiol Rev. 1999; 12: 564582.

27-Vir S, Grewel JS. Physiologic specialization in Ascochyta rabiei, the casual organism of gram blight. Ind Phytopath. 1974; 27: 524-526.

28-Dhingra OD, Sinclair JB. Basic Plant Pathology Methods. CRC Press, Inc. Boca Raton, Florida, 1985; Pp.132.

29-Barnett HL, Hunter BB. Illustrated genera of imperfect fungi. Minnesota: APS press; 1998; p. 241.

30-Neycee MA, Nematzadeh GHA, Dehestani A, Alavi M. Assessment of antifungal effects of shoot extracts in chinaberry (Melia azedarach) against 5 phytopathogenic fungi. Intr $J$ Agri Crop Sci. 2012; 4 (8): 474-477.

31-Perez C, Paul M, Bazerque P. An antibiotic assay by the agar well diffusion method. Acta Biologiae et Medicine Experimentalis. 1990; 15: 113-115.

32-Sofowora A. Medicinal plants and Traditional Medicine in Africa. Spectrum Books, Ibadan; 1993; p. 150

33-Harborne JB. Phytochemical Methods; A guide to modern techniques of plant analysis. Second Edition, London, Chapman and Hall, 1973; p. 221- 232.

34-Steel RGD, Torrie JH, Dicky DA. Principles and Procedures of Statistics: A Biometrical Approach, 3rd edition, 1997; pp: 352-358 McGraw Hill Book Co. Inc., New York.

35-Belisario A, Forti E, Corazza, Van Kestsren HA, 1999. First report of Myrothecium verrucaria from muskmelon seeds. Plant Path. 1999; 83: 589.

36-Domsch KH, Gams W, Anderson T. Compendium of soil fungi. ${ }^{2}$ nd Edition. IHW Verlag. Eching, Germany. 2007; p. 672.

37-Worapong J, Sun J, Newcombe G. First report of Myrothecium roridum from a gymnosperm. North American Fungi. 2009; 4:1-6. 
38-Zhao YJ, Li BJ, Shi YX, Xie XW. First Report of Myrothecium Leaf Spot of Common Bean in China Caused by Myrothecium roridum. Pl Dis. 2010; (1):127.

39-Zitter TA, Hopkins DL, Thomas CE. Compendium of cucurbit diseases. APS Press; 1996.

40-Bean GA, Fernando T, Jarvis BB, Bruton B. The isolation and identification of trichothecene metabolites from a plant pathogenic strain of Myrothecium roridum. I nat prod. 1984; (4):727-9.

41-Quezado Duval AM, Henz GP, Paz-Lima ML, Medeiros AR, Miranda BE, Pfenning LH, Reis A. New hosts of Myrothecium spp. in Brazil and a preliminary in vitro assay of fungicides. Braz J Microbiol. 2010; 41(1):246-52.

42-Taiga A, Suleiman MN, Sule W, Olufolaji DB. Comparative in vitro inhibitory effects of cold extracts of some fungicidal plants on Fusarium oxysporium mycelium. Afr J Biotech. 2008; 7(18).

43-Liu IX, Durham DG, Richards ME. Vancomycin resistance reversal in enterococci by flavonoids. J Pharm Pharmacol, 2001; 53: 129-132.

44-Singh R, Singh S, Kumar S, Arora S. Evaluation of antioxidant potential of ethyl acetate extract/fractions of Acacia auriculiformis. A Cunn Food Chem Toxicol. 2007; 45:12161223.

45-Maji MD, Chattopadhyay S, Kumar P, Saratchandra B. In vitro screening of some plant extracts against fungal pathogens of mulberry (Morus spp.). Arch Phytopath Pl Prot. 2005; 38(3):157-64.

46-Vaghasiya Y, Chanda SV. Screening of methanol and acetone extracts of fourteen Indian medicinal plants for antimicrobial activity. Turk J Biol. 2007; 31: 243-248.

47-Jana S, Shekhawat GS. Phytochemical analysis and antibacterial screening of in vivo and in vitro extracts of Indian medicinal herb: Anethum graveolens. Res J Med Plant. 2010; 4: 206-212.

48-Brighente IMC, Dias M, Verdi LG, Pizzolatti MG. Antioxidant activity and total phenolic content of some Brazilian species. Pharm Biol. 2007; 45: 156-161.

49-Ali SS, Kasoju N, Luthra A, Singh A, Sharanabasava H, Sahu A, Bora U. Indian medicinal herbs as sources of antioxidants. Food Res Int. 2008; 41: 1-15. 
Management of Myrothecium leaf spot

\section{Erratum}

In Article "Antifungal Potential of Indigenous Medicinal Plants against Myrothecium Leaf Spot of Bitter Gourd (Momordica charantia L.)", with DOI number: http://dx.doi.org/10.1590/16784324-2017160395, published in journal Brazilian Archives of Biology and Technology, vol. 60, the 01 page.

That read:

“http://dx.doi.org/10.190/1678-4324-2017160395"

Read:

“'http://dx.doi.org/10.1590/1678-4324-2017160395" 